\title{
Two alcoholic sources in the preparation, chemical characterization and acceptability of artisanal dovialis liqueurs
}

\author{
Fabíola Villa ${ }^{* *}$ Maria Cristina Copello Rotili ${ }^{1}$ (D) Daniel Fernandes da Silva ${ }^{1}$ \\ Gilberto Costa Braga $^{1}$ (D) Solivan Rosanelli ${ }^{1} \quad$ Tatiane Eberling $^{1}$ (D)
}

${ }^{1}$ Centro de Ciências Agrárias (CCA), Universidade Estadual do Oeste do Paraná (Unioeste), 85960-000, Marechal Cândido Rondon, PR, Brasil. E-mail: fvilla2003@hotmail.com. "Corresponding author.

\begin{abstract}
This study evaluated two alcoholic sources in the preparation, chemical characterization, and acceptability of homemade Kei apple liqueurs. Kei apple fruits were harvested from 4-year-old plants and immediately transported to the laboratory. The liqueur prepared with vodka + fruits without the epicarp was named L1; the liqueur prepared with sugarcanespirit+ fruits with the epicarp and sliced was named L2. The infusion or alcoholic maceration stage was then performed, mixing the fruits with the alcoholic liquid. After the preparation of the alcoholic extract, the chemical characterization of the final products was performedand after 60 days, the sensory analysis and acceptabilityof the product were conducted. The experimental design was entirely randomized, in a $2 \times 2$ factorial scheme (two types of fruits $\times$.two types of alcohol), containing three samples of liqueurs per replicate and six replicates per experimental plot. The liqueurs suited the parameters fixed by the Brazilian legislation for the chemical evaluation of these products. As for sensory analysis, L1 had good acceptability from tasters, with apurchase intention by $71 \%$ of them.
\end{abstract}

Key words: Dovyalis sp., alcoholic beverage, alcohol by volume, chemical parameters, sensory analysis.

Duas fontes alcoólicas no preparo, caracterização química e aceitabilidade de licores artesanais de doviális

RESUMO: Objetivou-se com o presente trabalho avaliar duas fontes alcoólicas no preparo, caracterização química e aceitabilidade de licores artesanais de doviális. Frutos de doviálisforam colhidos de plantas de 4 anos e imediatamente transportados ao laboratório. Chamouse de L1 o licor que fora preparado com vodca + frutos sem epicarpo e L2 o licor preparado com aguardente de cana-de-açúcar + frutos com epicarpo e fatiados. Na sequência realizou-se a etapa de infusão ou maceração alcoólica, misturando os frutos + líquido alcoólico. Após o preparo do extrato alcoólico, foi realizada a caracterização química dos produtos finais e, após 60 dias, a análise sensorial e aceitação do produto. O delineamento experimental foi inteiramente casualizado, em esquema fatorial $2 \times 2$ ( 2 tipos de frutos $x 2$ tipos de álcool), contendo três amostras de licores por repetição e seis repetições por parcela experimental. Os licores se enquadraram nos parâmetros previstos pela legislação brasileira na avaliação química dos produtos. Quanto a análise sensorial, houve boa aceitabilidade dos provadores do L1 e intenção de compra de $71 \%$ dos provadores.

Palavras-chave: Dovyalis sp., bebida alcoólica, teor alcoólico, parâmetros químicos, análise sensorial.

\section{INTRODUCTION}

In Brazil, Dovyalis sp. (Kei apple) is still considered an exotic fruit tree since there are few studies regarding this species. This plant belongs to the Salicaceae family and is originated from Southern India or Ceylon Island, from where it has spread throughout the world, adapting to different growing regions, including Brazil (BORGES et al., 2010; RINALDI et al., 2017).

Kei apple fruits are spherical, approximately $2-3 \mathrm{~cm}$ in diameter, juicy, and with anacidic pulp. They are highly perishable and are used mainly in beverage processing, with characteristics favorable to the manufacture of liqueurs, such as pleasant color and taste (SILVA et al., 2011; ROTILI et al., 2021). In recent years, there has been great interest in research on the technological use of this fruit. This can be attributed to the nutritional properties of this fruit and bioactive compounds and minerals found in it (BOCHI et al., 2014; ROTILI et al., 2018).

The definition of liqueurs reported in the literature is quite diverse; however, the main elements that constitute aliqueur, a drink referred to "by mixture,"are stated to come from alcoholic products 
and precursors of taste and sweetness. According to current Brazilian legislation (BRAZIL, 2009), the liqueur is a beverage with an alcohol by volume of $15 \%$ to $54 \%$ at a temperature of $20{ }^{\circ} \mathrm{C}$, with a sugar content of $>30 \mathrm{~g} \mathrm{~L}^{-1}$, made with an alcoholic part and a nonalcoholic part of plantor animal origin (TEIXEIRA et al., 2007).

Processed products such as liqueurs often have variations in raw materials, alcohol by volume, and sugar. The appropriate combination of alcohol by volume and sugar quantity plays a key role in consumer acceptance (TEIXEIRA et al., 2007). However, it is worth mentioning that the preference for a given alcoholic content of a liqueur is related to the combination of sweet taste, alcoholic content, and fruit flavor. Nonetheless, there is a lack in the literature of studies on the sensory analysis of fruit liqueurs to establish this measureand obtain greater product acceptability.

Due to the particular characteristics of sugar-canespirit and vodka (alcohol by volume between 36 and $54 \%$ at $20{ }^{\circ} \mathrm{C}$ ), their use in the production of liqueurs, incorporating different raw materials and giving them a characteristic taste, is quite common(BRAZIL, 2009). The artisanal production of liqueurs is an interesting option to provide increased family income as the processing requires simple technology, the final product is marketed at room temperature, and it has a long shelf life.

The sensory analysis of a beverage aims to evaluate its acceptability, individually or in relation to others through several methods, using attributes such as flavor, color, appearance, odor, and texture (OLIVEIRA \& SANTOS, 2011). Given the above, this study evaluated two alcoholic sources in the preparation, chemical characterization, and acceptability of homemade Kei apple liqueurs.

\section{MATERIALS AND METHODS}

Fruits from Kei apple (Dovyalis hebecarpa) were harvested from 4-year-old plants in the orchard of the experimental farm belonging to the State University of Western Paraná (Unioeste), in Marechal Candido Rondon, Paraná State, Brazil. These were collected between 8 and 9 a.m. in polyethylene boxes when they were ripe and with a purple epicarp. Subsequently, they were transported to the Post-Harvest Technology Laboratory of Unioeste for liqueur preparation.

After the arrival of the material in the laboratory, the fruits were sanitized in running water, and those with lesions were discarded and calyxes were removed from the healthy fruits. Then, the liqueurs were prepared according to the flow chart proposed below (Figure 1).

In half of the experimental lot, the fruits were peeled by hand, separating the epicarp from the mesocarp and endocarp. In the other half, the fruits were sliced with a knife, keeping the epicarp. The liqueur prepared with vodka (37.5\% alcohol by volume) + fruits without epicarp was named L1, and the liqueur made with sugar-canespirit ( $39 \%$ alcohol by volume) + fruits with epicarp was named L2 (Figure 1). In the sensory analysis, L1 and L2 liqueurs were coded as 234 and 129, randomly defined by a lot.

In the infusion stage, also known as alcoholic maceration, the Kei apple fruits (whole and a halved) were packed in $1 \mathrm{~L}$ glass vials. The first glass container contained $450 \mathrm{~g}$ of fruit without epicarp, to which $800 \mathrm{~mL}$ of vodka was added. The second glass container contained $450 \mathrm{~g}$ of fruit, with epicarp and sliced in half, to which $800 \mathrm{~mL}$ of sugarcane spirit was added. The mixtures were homogenized for 5 min each and stored for 15 days in a suitableplace atan ambient temperature of $23^{\circ} \mathrm{C}$.

After 15 days of infusion of the products from the previous stage (alcoholic maceration), they were filtered in fine No. 7 plastic sieves $(2.83 \mathrm{~mm}$ mesh size) to separate the fruits from the liquid, thus obtaining an alcoholic extract.

For the syrup preparation, a previously cleaned stainless steel pan was used, where $100 \mathrm{~g}$ of sugar was transferred andsoon after, $300 \mathrm{~mL}$ of drinking water was added. The mixture was homogenized and thenboiled at $100{ }^{\circ} \mathrm{C}$ for 10 min. The pan was removed from the fire and then placed in a container of water at room temperature to cool. After cooling, the mixture was left on hold for the next step.

After the infusion time, the syrup was mixed with the alcoholic extract at room temperature and homogenized for $5 \mathrm{~min}$ to obtain the liqueurs. The liqueurs were bottled in properly sanitized glass containers sterilized with water at $100^{\circ} \mathrm{C}$ and identified as L1 and L2. Glass containers had a capacity of $1 \mathrm{~L}$ and were sealed with a lid, remaining at rest for 30 days in a place with no incident light until the sensory analysis of the products was performed.

The experimental design was entirely randomized, in a $2 \times 2$ factorial scheme (two types of fruits $\times$ two types of alcohol), containing three samples of liqueurs per replicate and six replicates per experimental plot.

The liqueurs produced were chemically characterized by the following analyses: alcohol 


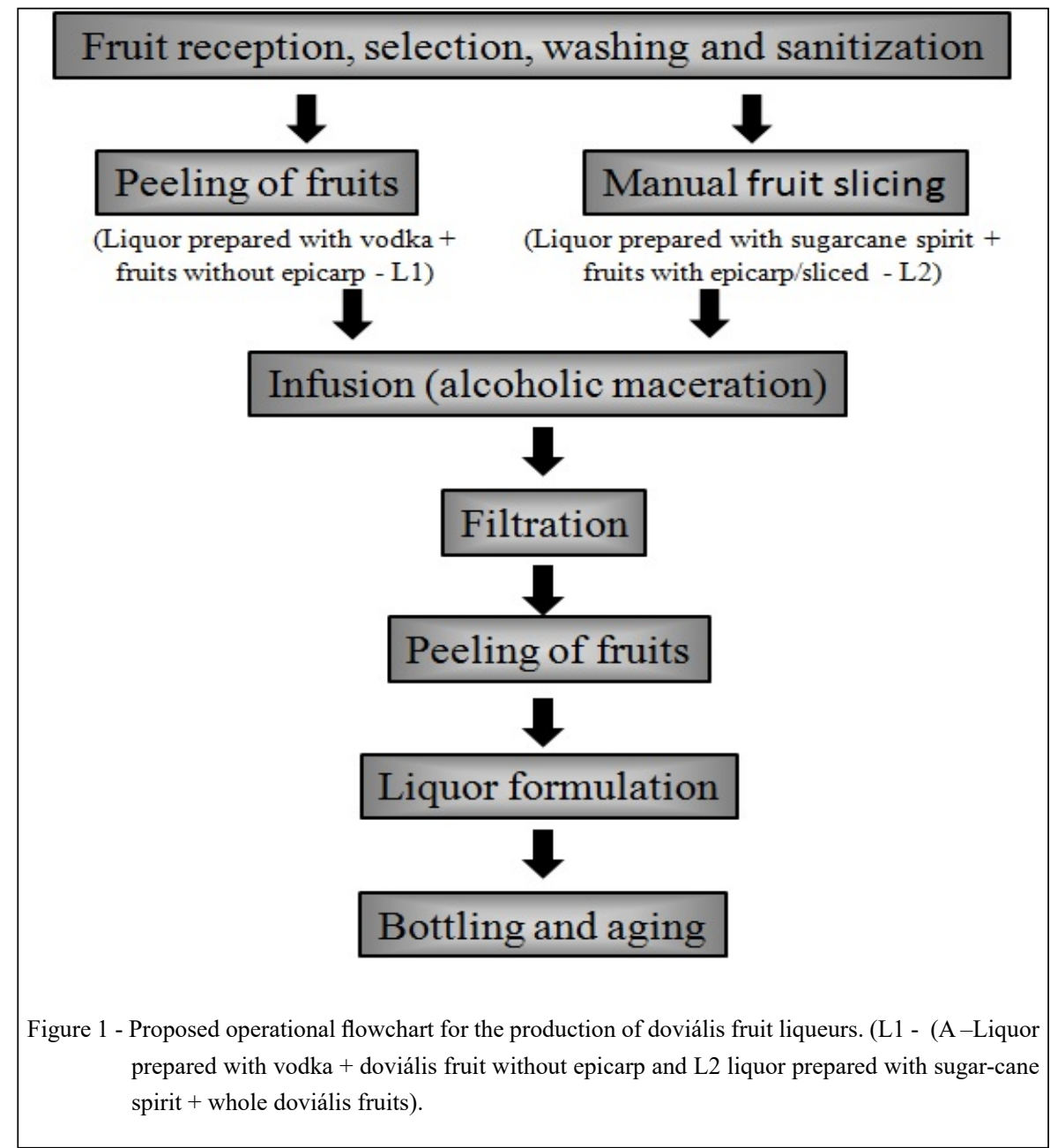

by volume (\%), which was determined with a Gay-Lussacalcoholmeter; $\mathrm{pH}$,measured with a digital potentiometer; titratable acidity $(\mathrm{g}$ of citric acid $\left.100 \mathrm{~g}^{-1}\right)$, measured bytitration of $5 \mathrm{~mL}$ of the homogenized liquid and dilutionin $10 \mathrm{~mL}$ of distilled water, with standardized $1 \mathrm{~N}$ sodium hydroxide solution, using phenolphthalein (IAL, 2008) and soluble solids (SS) as indicators, and results expressed in Brix. The chemical variables followed the methodology described by the Adolfo Lutz Institute (IAL, 2008) and were performed in triplicate.

After $60 \pm 7$ days of maturation, the liqueurs were submitted for acceptance tests (taste, color, texture, and aroma) and purchase intention (would or would not buy) with the samples randomly allotted to the 60 untrained voluntary tasters, according to the procedure described by MEILGAARD et al. (2007). The tasters were randomly drawn from among individuals of both sexes, aged between 20 and 45 years, who had different education levels, and were consumers of alcoholic beverages.

Samples of $10 \mathrm{~mL}$ were served individually in $25 \mathrm{~mL}$ disposable cupscoded L1 and L2, chosen randomly, and at room temperature. The seven-point hedonic mixed structured scale, which ranged from 1 ('I really disliked it') to 7 ('I liked it a lot'), was used for the product acceptance and purchase intention test.

The results obtained in the chemical characterization of liqueurs, sensory test, and intention to purchase were statistically evaluated through the statistical program Sisvar (FERREIRA, 2011), using an analysis of variance (ANOVA 
and Tukey's testat 5\% probability of error, for comparison of means between the samples.

\section{RESULTS AND DISCUSSION}

Table 1 shows the results of chemical evaluations for the two types of liqueurs obtained from processing Kei apple fruits. There was asignificant difference in the alcohol by volumeof both liqueurs with higher alcohol by volume in L1. This difference in alcohol by volume is because the alcohol contained in L2 has evaporated more than in L1, a characteristic from sugarcane spirit (OLIVEIRA et al., 2015). Liqueurs $(\mathrm{L} 1=26 \%$ and $\mathrm{L} 2=23 \%)$ are within the range required by Brazilian legislation (BRAZIL, 2009 ), which is $15 \%$ to $54 \%$.

Most industrial fruit liqueurs have their alcohol by volume declared on the label between 18 and $25 \%$. In addition, liqueurs with alcohol by volume between $23.8 \%$ and $27.2 \%$ are classified as semi-fine liqueurs (SANTOS et al., 2018). Therefore, the liqueurs prepared in this study can be classified as possible industrial and semi-fine. The alcohol range preferred by connoisseurs of alcoholic beverages and the general population is below $25 \%$ (TEIXEIRA et al., 2011). Therefore, the two samples prepared in the present study could be readily accepted by connoisseurs of this type of beverage.

Regarding the $\mathrm{pH}$ of the liqueurs, significance was observed, with a variation between 3.11 and 3.22, and the higher value in L1. Fruits of the Kei apple are acidic with a $\mathrm{pH} \sim 3.2$, limiting their fresh consumption, but showing their suitability for processing into products such as liqueurs (VIEIRA et al., 2010). This explains why the $\mathrm{pH}$ range of liqueurs is close to the $\mathrm{pH}$ of fresh fruits (ROTILI et al., 2018). Liqueurs prepared with acid fruits and low $\mathrm{pH}(\leq 3.5)$ tend to be more alcoholic and havea higher amount of sugar syrup (TEIXEIRA et al., 2011). The pH values in this range are appreciated by the beverage industry, as there is an increase in the product lifetime. Moreover, these values represent a limiting factor for the growth of pathogenic and deteriorating bacteria, as well as favor the stability of ascorbic acid as this vitamin has greater stability at low $\mathrm{pH}$ (OLIVEIRA \& SANTOS, 2011).

Table 1 shows high acidity in the liqueur samples, with higher values in L1. As in the fruits (ROTILI et al., 2018), the Kei apple liqueurs of this study had low $\mathrm{pH}$, high acidity, and a low degree of sweetness ( $\left({ }^{\circ}\right.$ Brix/acidity ratio) and thus can be a wellaccepted product by the consumer. Moreover, the acid condition of a liqueur leads to greater stability of the anthocyanins, which are important sources of phenols and imparta pink color to the final product (VIEIRA et al., 2010).

The SS also showed significant results, ranging between 30.75 and $37.25^{\circ}$ Brix, and once again, the L1 stood out. The high content of SS present in L1 indicates that the fruits of Kei applehave a considerable quantityof dissolved solids in this drink comparedto L2. The differences observed in Table 1 of the chemical variables between the two prepared liqueurs are mainly due to the difference between the alcoholic raw materials, with L1 being prepared with vodka and L2 with sugar-canespirit. According to OLIVEIRA et al. (2015), the ripeness of fruits, the amount of sugar added in the preparation of syrup, and the raw material used to prepare the liqueur influence the SS amount in the final product.

Figure 2A and 2B show the percentage results of the acceptability test for the taste, color, texture, and aroma of these liqueurs.

Table 1 - Chemical characterization of doviális fruit liqueurs (L1 and L2).

\begin{tabular}{lrr}
\hline Chemical variables & L1 & L2 \\
\hline Alcohol contente $\left({ }^{\circ} \mathrm{GL}\right)$ & $25,00 \pm 0,00 \mathrm{a}^{*}$ & $23,00 \pm 0,00 \mathrm{~b}$ \\
$\mathrm{pH}$ & $3,22 \pm 0,02 \mathrm{a}$ & $3,11 \pm 0,00 \mathrm{~b}$ \\
Titratable acidity $\left(\mathrm{g}\right.$ of citric acid $\left.100 \mathrm{~g}^{-1}\right)$ & $10,62 \pm 0,11 \mathrm{a}$ & $9,78 \pm 0,05 \mathrm{~b}$ \\
Soluble solids $\left({ }^{\circ} \mathrm{Brix}\right)$ & $37,25 \pm 0,27 \mathrm{a}$ & $30,75 \pm 0,10 \mathrm{~b}$ \\
\hline
\end{tabular}

${ }^{*}$ Means followed by different letters on the line differ statistically from each other, using the Tukey's test, at 5\% probably of error. 


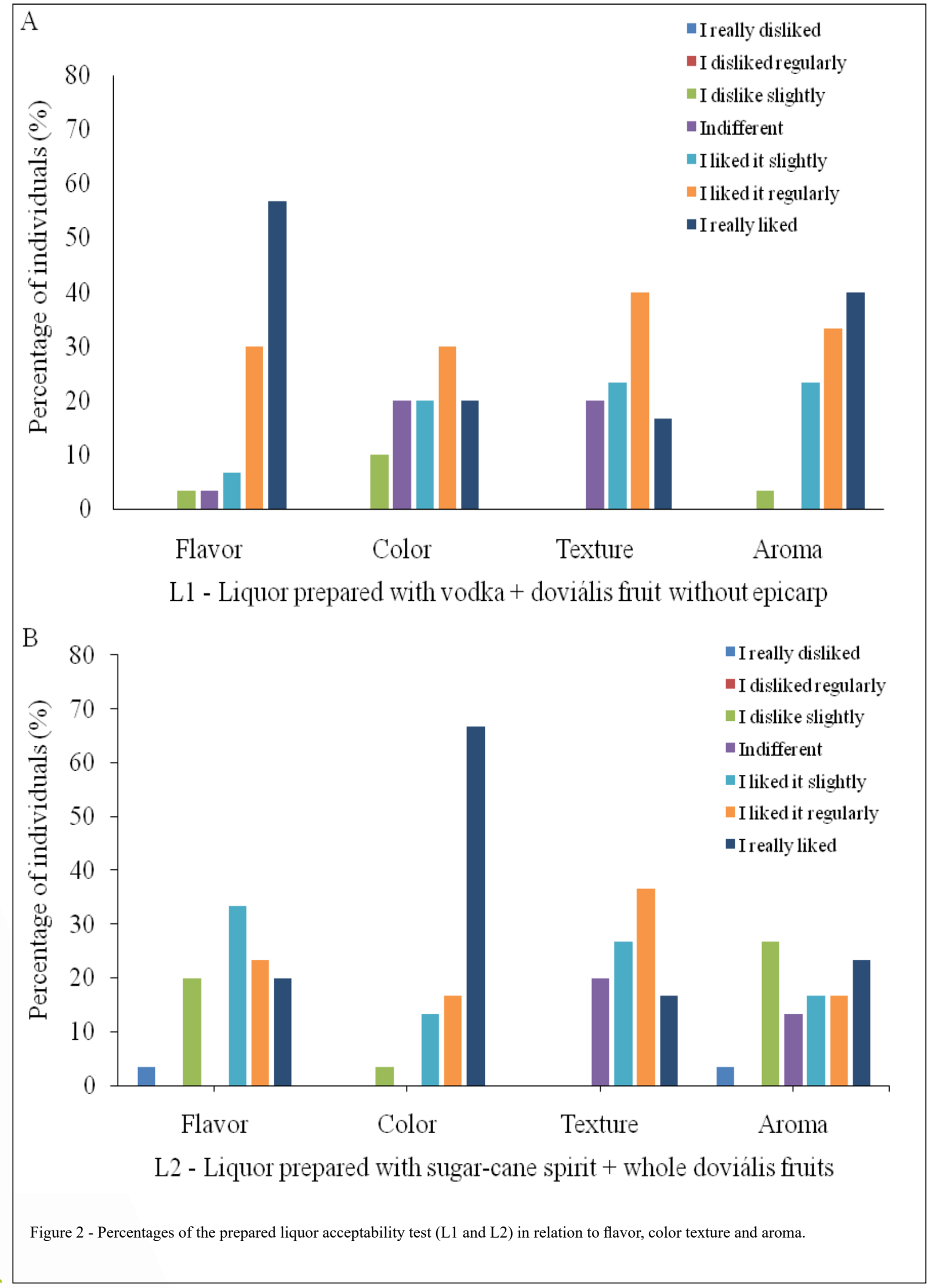

Ciência Rural, v.51, n.11, 2021. 
The attributes of taste and aroma had the highest acceptance rate (71\%) for L1. Contrarily, the color had the highest acceptance rate for L2 (71\%). The appearance or color of a product is one of the most important factors related to its acquisition in the market, followed by the attributes of flavor, aroma, and texture (DUTCOSKY, 2013). Based on the results obtained from the tasters in the sensory characterization test regarding the flavor attribute, L1 (the formulation with vodka and fruits without the epicarps raw material that accentuates the fruit flavor) hada more pleasant taste than L2. As for color, although the tasters really liked L1, they ended up preferring L2 (Figure 2A and 2B). This finding was because L2 contained sugar-canespirit and sliced fruits of Kei apple with the epicarpas raw material, giving the final product a more intense color, which pleased $71 \%$ of the tasters. The color of the final product often depends on the fruit chosen and its physical and chemical stability during storage (OLIVEIRA et al., 2015).

As for consistency, $71 \%$ of the tasters really liked both formulations (Figure 2A and 2B). It is possible that the type and amount of sugar used in the preparation of the syrup resulted in a less viscous liqueur, which consistently pleased the tasters. The amount of final raw material in the liqueur associated with the type of fruit used influences the consistency of the liqueur, and the same pattern was observed by ALVES and MENDONÇA (2011). These authors performed an acceptability test of açai liqueur formulations and reported that $70 \%$ of the tasters liked the consistency of the liqueurs that contained proportionally less sugar-canespirit and more fruit.

Regarding the aroma of the final product, $71 \%$ of the tasters really liked L1 (prepared with vodka). Once again, the raw material used (vodka) in this formulation pleased tasters more than sugarcane spirit. As for the intention of purchasing the liqueur of their preference, $71 \%$ of tasters indicated that they would prefer to buy L1 due to the characteristics of the product (taste, aroma, color, and texture). In acceptance tests of açai and camu-camu liqueurs, $>70 \%$ of tasters also indicated that they could buy and consume the product (ALVES \& MENDONÇA, 2011; VIEIRA et al., 2010); these come from fruits that are very similar to Kei apple concerning their bioactive and functional compounds (ROTILI et al., 2018).

Studies on the use of small fruits and their processing are still scarce in the literature. Thus, further investigation is required on the use of functional fruits, types, and concentrations of raw materials, sugar sources, and the acceptability by final consumers.

\section{CONCLUSION}

The liqueurs of this study fit the parameters fixed by the Brazilian legislation for the chemical evaluation of these products and can be classified as fine or industrial. As for the sensory analysis, there was good acceptability of L1 by the tasters. This liqueur was prepared with vodka and whole Kei apple fruits without the epicarp. Regarding the purchase intention, $71 \%$ of the tasters would buy the L 1 option.

\section{ACKNOWLEDGMENTS}

This study was financed in part by the Coordenação de Aperfeiçoamento de Pessoal de Nível Superior (CAPES), Brasil.

\section{DECLARATION OF CONFLICT OF INTERESTS}

The authors declare no conflict of interest. The founding sponsors had no role in the design of the study; in the collection, analyses, or interpretation of data; in the writing of the manuscript, and in the decision to publish the results.

\section{AUTHORS' CONTRIBUTIONS}

All authors contributed equally for the conception and writing of the manuscript. All authors critically revised the manuscript and approved of the final version.

\section{REFERENCES}

ALVES, Y.F.M.; MENDONÇA, X.M.F.D. Elaboração e caracterização sensorial e funcional de um típico amazônico a base de açaí (Euterpe oleracea). Revista Brasileira de Tecnologia Agroindustrial, v.5, p.559-572, 2011. Available from: <https:// periodicos.utfpr.edu.br/rbta/article/view/742>. Accessed: Mar. 16, 2020. doi: 10.3895/S1981-36862011000200008.

BOCHI, V. C. et al. Polyphenol extraction optimization from Ceylon gooseberry (Dovyalis hebecarpa) pulp. Food Chemistry, v.164, p.347-354, 2014. Available from: <https://doi.org/10.1016/j. foodchem.2014.05.031>. Accessed: Mar. 18, 2020. doi. org/10.1016/j.foodchem.2014.05.031

BORGES, G. et al. Identification of flavonoid and phenolic antioxidants in black currants, blueberries, raspberries, red currants, and cranberries. Journal of Agricultural and Food Chemistry, v.58, p.3901-3909, 2010. Available from: <https:// pubmed.ncbi.nlm.nih.gov/20000747/>. Accessed: Nov. 17, 2019. doi: $10.1021 / \mathrm{j} 902263 \mathrm{n}$.

BRASIL. Ministério da Agricultura, Pecuária e Abastecimento. Decreto $\mathrm{n}^{\circ}$ 6.871, de 4 de julho de 2009. Dispõe sobre a padronização, a classificação, o registro, a inspeção, a produção e a fiscalização de bebidas. Diário Oficial [da] República Federativa do Brasil. Brasília, DF, 05 de jun. 2009. Available from: <http:// www.agricultura.gov.br/assuntos/vigilancia-agropecuaria/ivegetal/ bebidas-arquivos/decreto-no-6-871-de-4-de-junho-de-2009.doc/ view>. Accessed: 20 mar. 2020. 
DUTKOSKI, S.D. Análise sensorial de alimentos. Curitiba: Champagnat, 2013. 123p.

FERREIRA, D. F. Sisvar: a computer statistical analysis system. Ciência \&Agrotecnologia, v.35, p.1039-1042, 2011. Available from: <http://www.scielo.br/scielo. php?script $=$ sci_arttext\&pid $=$ S1413-70542011000600001\&lng $=$ en\&nrm=iso $>$. Accessed: Mar. 18, 2020. doi: 10.1590/S141370542011000600001 .

IAL. INSTITUTO ADOLFO LUTZ. Métodos físico-químicos para análise de alimentos. São Paulo, 2008. 1020p.

MEILGAARD, M. et al. Sensory evaluation techiniques. 4a. ed. Boca Raton: CRC Press, 2007. 448p.

OLIVEIRA, E. R. et al. Production, characterization and acceptability of different alcohol-based pineapple liqueurs. Revista Verde de Agroecologia e DesenvolvimentoSustentável， v.10， p.108-114， 2015. Available from: <https:/www.gvaa.com.br/revista/index.php/ RVADS/article/view/2736>. Accessed: Mar. 17, 2020. doi: 10.18378/rvads.v10i1.2736.

OLIVEIRA, E. N. A; SANTOS, D. C. Processamento e avaliação da qualidade de licor de açaí (Euterpe oleracea Mart.). Revista do Instituto Adolfo Lutz, v.70, p.534-41, 2011. Available from: $\quad<$ http://periodicos.ses.sp.bvs.br/scielo.php?script=sci arttext\&pid $=$ S0073-98552011000400014\&lng=pt\&nrm $=$ iso $>$. Accessed: 27 mar. 2020.

OLIVEIRA, E. N. A. et al. Estabilidade física e química de licores de graviola durante o armazenamento em condições ambientais. Revista Brasileira de Engenharia Agrícola e Ambiental, v.19, p.245-251, 2015. Available from: <http://www.scielo.br/scielo. php?script $=$ sci_arttext\&pid=S1415-43662015000300245\&lng=en \&nrm=iso>. Accessed: 20 mar. 2020. doi.org/10.1590/1807-1929/ agriambi.v19n3p245-251.

RINALDI, A.R. et al. Stem cuttings and substrates in Dovyalis asexual propagation. Comunicata Scientiae, v.8, p.587-595, 2017. Available from: <https://comunicatascientiae.com.br/comunicata/ article/view/1986>. Accessed: 20 mar. 2020. doi: 10.14295/ cs.v8i4.1986.
ROTILI, M. C. C. et al. Bioactive compounds, antioxidant and physic-chemical characteristics of the dovyalis fruit. Acta Scientiarum. Agronomy, v.40, e35465, 2018. Available from: $<$ https://www.scielo.br/scielo.php?script=sci arttext\&pid $=$ S1807-86212018000100613 $>$. Accessed: 19 mar. 2020. doi: 10.4025/actasciagron.v40i1.35465.

ROTILI, M. C. C. et al. Caracterização de um fruto nutracêutico, seu aspecto nutricional e análise sensorial de geleia. Ciência Rural, v.51, e20200310, 2021. Available from: <https://www.scielo. br/scielo.php?pid=S0103-84782021000100751\&script $=$ sci abstract\&tlng=pt $>$. Accessed: 19 mar. 2020. doi: <http://dx.doi. org/10.1590/0103-8478cr20200310>.

SANTOS, K. M. et al. Caracterização físico-química, determinação de minerais e avaliação do potencial antioxidante de licores produzidos artesanalmente. Multi-ScienceJournal, v.1, p.54-61, 2018. Available from: <https://www.ifgoiano.edu. $\mathrm{br} /$ periodicos/index.php/multiscience/article/view/583/477>. Accessed: 25 mar. 2020.

SILVA, J. A. A. et al. Caracterização físico-química de frutos de clones de doviális (Dovyalis abyssinica Warb). Revista Brasileira de Fruticultura, v. esp. 466-472, 2011. Available from: <http:// www.scielo.br/scielo.php?script $=$ sci_arttext\&pid $=\mathrm{S} 0100$ 29452011000500062\&lng=en\&nrm=iso $>$. Accessed: 26 mar. 2020. doi: 10.1590/S0100-29452011000500062.

TEIXEIRA, L. J. Q. et al. Testes de aceitabilidade de licores de banana. Current Agricultural Science and Technology, v.13, p.205-209, 2007. Available from: <https://periodicos.ufpel.edu.br/ ojs2/index.php/CAST/article/view/1362/1347>. Accessed: 18 mar. 2020. doi: 10.18539/CAST.V13I2.1362.

TEIXEIRA, L. J. Q. et al. Tecnologia, composição e processamento de licores. Enciclopédia Biosfera, v.7, p.1-17, 2011. Available from: $\quad<$ http://www.conhecer.org.br/enciclop/2011a/agrarias/ tecnologia.pdf >. Accessed: 23 mar. 2020.

VIEIRA, V. B. et al. Produção, caracterização e aceitabilidade e licor de camu-camu (Myrciaria dubia (H.B.K.) Mc Vaugh). Alimentos e Nutrição, v.21, p.519-522, 2010. Available from: $<$ http://serv-bib.fcfar.unesp.br/seer/index.php/alimentos/article/ viewFile/1212/a3v21n4>. Accessed: 26 mar. 2020. 